\title{
A RÍTUS MINT BELÉPÉS \\ A VALLÁS ÁTMENETI TERÉBE
}

SIBA BALÁZS

„Az élet 10\%-ban szól arról, ami velem történik és 90\%ban arról, ahogy erre reagálok." - John C. Maxwell ${ }^{1}$

Ritual cements human life. ${ }^{2}$

\begin{abstract}
Rites as entries to the intermediate space of religion

There is an intermediate area of experiencing, to which inner reality and external life both contribute. Space in-between is a peculiar phenomenon because we live in it without noticing it. It cannot be described, because the world present in it is in a blurred, half-formed stage, where inside and outside, the personal and collective cannot be distinguished from each other. This is a transitional space of experience where inner reality and outer life are both formative powers. Religion (like arts, and culture in general) belongs to this intermediate space. In this study we investigate from an anthropological and psychological point of view how rites help the believer to enter this intermediate space of religion.
\end{abstract}

Talán előfordult már velünk, hogy amikor egy előadást hallgattunk, az idő egy részében nem voltunk teljesen jelen aktív hallgatóként? Talán régebbi eseményekre vagy jövőben ránk várókra gondoltunk, testben ugyan jelen voltunk, de mégis álmodozva, gondolatainkba mélyedve kevésbé figyeltünk a körülöttünk zajló eseményekre. A reggeli felkeléstől egészen a nap végéig, míg újra álomba nem merülünk, az éber időnk egy jelentős részét úgy töltjük, hogy nem csak az „itt és most-ban" vannak a gondolataink. Egyes kutatások szerint éber időnk legalább 30

\footnotetext{
${ }^{1}$ Zakari: 3.

${ }^{2}$ Solomon, et al.: 1.
} 
százaléka daydreaming, mint wandering. ${ }^{3}$ Ez egy olyan köztes tér-idő, ami az én és a másik, az álom és az éber jelenlét közti világban jön létre. Számos formát ölthet, és többféle tartalommal telik meg ez a tér és idő közti világ.

E tanulmány vallásantopológiai és valláslélektani szempontok alapján a valóságnak a köztes terével foglalkozik, és az azzal, hogy a rítusok miként segítenek a vallás köztes terébe belépni.

\section{AZ ÉLMÉNYMEGÉLÉS KÖZTES TERÜLETE}

A fókuszált jelenlét állapota és az éjszakai alvás között sokféle átmenet van és lehet jelen mindennapi életünkben. Van olyan, amikor tudjuk, hogy a valós térben és időben hol vagyunk, de fantáziánk más időben vagy térben kalandozik. Ilyen lehet nemcsak a daydreaming, hanem a virtuális valóságban tett kalandozás is, egy mozi, egy jó mese magával ragadhatja képzeletünket. Nem feltétlenül feledkezünk el a valós térről és időről, ugyanakkor valóságos lehet számunkra egy-egy olyan átmeneti vagy ha úgy tetszik, játéktér, amelynek jelentőséget tulajdonítunk életünkben. A köztes tér sajátos jelenség, hiszen mindig benne élünk, mégsem „tudunk róla”. Megfoghatatlan, hiszen benne a valóság elmosódik, kiformálatlan valamiként létezik, melyben nem lehet szétválasztani a külsőt a belsőtől, a sajátot a közösségitől. Ahogy Winnicott fogalmaz: „Az én feltevésem az, hogy ha szükségünk van erre a kettős felosztásra, szükségünk van egy harmadikra is: az emberi lény életének egy harmadik részére, az pedig az élménymegélés köztes területe, amelyhez a belső realitás éppúgy hozzájárul, mint a külvilág."

Ez egy olyan átmeneti tere a tapasztalásnak, amelyben a belső realitás és a külső élet egyaránt formáló erő. Németh Dávid Winnicott elmélete kapcsán írja: „(...) »Intermediális« vagy "potenciális« térnek nevezi Winnicott az illuzórikus átélési területet, a benne lévő szimbólikus tárgyat pedig »átmeneti tárgynak«. (...) Az átmeneti tárgyak jelentősége abban áll, hogy azok egyszerre tartoznak a valóságos tárgyi világához és a gyermek vágyvilágához, ezért képesek közvetíteni a fantázia és a valóság között. Köztes térre az embernek egész életében szüksége van, később azonban a köztes teret kevésbé fantáziával kiegészített tárgyak, mint inkább kreativitás, játék, művészet és vallási rítusok és eszmék töltik ki. Enélkül nem lehetne kapcsolatunk az általunk tapasztalt, közvetlenül azonban mégsem elérhető valósággal."

\footnotetext{
${ }^{3}$ Weinschenk: 68-69.

${ }^{4}$ Winnicott: 102.

${ }^{5}$ Németh: 146.
} 
A legtöbb ember óvodáskorának végére vagy kisiskolás korára már képes elválasztani, ugyanakkor képes együtt is megélni az „itt és most” és az átmeneti tér kettős valóságát. ${ }^{6}$ Például egy kisfiú teljes valóságával képes elmélyülni egy szerepjátékban, indiánokat üldözve az udvaron, ugyanakkor képes a postás kérdésére válaszolni, aki éppen megérkezve a gyermek szüleit keresi. Majd miután elmondta, hogy szülei a házban vannak, máris visszatér a játék terébe, és folytatja az indiánok üldözését. Egyszerre képes jelen lenni a valós térben és időben, ugyanakkor teljesen beleéli magát, és jelentést és jelentőséget tulajdonít annak a játéktérnek és időnek is, amiben szintén jelen van. ${ }^{7} \mathrm{Ez}$ az , „intermediális tér” ${ }^{8}$ különös dolog az ember életében, hiszen olyan „játéktér”, melynek szabályai vannak, szubjektív s egyben komoly dolog.

Életünkben számos ilyen „játéktér” létezik. Például, ha színházba megyünk, a színpad játéktere arra a két órára átlényegül, és jelentést és jelentőséget tulajdonítunk annak, ami ott megvalósul és bevonz bennünket. Vannak olyan játékterek, ahol nem is kell személyesen jelen lennünk, mégis hat ránk. Például, ha a televízióban egy futballmeccset nézünk. A meccs menete és a kedvenc csapatunk győzelme vagy veresége kihat közérzetünkre, akár még a következő napokban is, mert jelentést és jelentőséget tulajdonítottunk annak a játéknak. Az internet megjelenésével pedig a lehetséges terek fantáziavilága számos lehetőséget kínál, és nagymértékben visszahat a valós idejü itt és most tér érzékelésünkre is. Az okostelefonok elterjedésével az átmeneti tér egy gombnyomásnyira került sokaktól.

\section{A VALLÁS ÁTMENETI TERE}

A valóság tényszerű adatai csak egy része annak, ahogy emberként a valóságot látjuk. A tényekhez füzött vélemények, magyarázatok füzik gondolati láncolattá azt, ahogy a világot magunk körül értelmesnek és az életünket élhetőnek látjuk. Gerkin így fogalmaz: „Az értelemképzés folyamata teszi az embert emberré.” Életünknek nemcsak velejárója, hanem szükséglete is, hogy ki tudjunk lépni a mindennapok világából, s ebben a köztes térben feltöltődjünk, új szempontokat, élményeket szerezzünk. Ennek az átlépési, kilépési szükségletnek a mai társadalomban sokféle formája létezik, és az emberiség történelme során számos lehetőséget, „kaput” nyitott arra, hogy a jelentést és jelentőséget adó átmeneti terekbe belépjünk.

\footnotetext{
${ }^{6}$ Vö. Kodácsy-Simon-Szabóné: 92.

${ }^{7}$ Paloutzian: 146.

${ }^{8}$ Winnicott: 2.

${ }^{9}$ Gerkin: 40.
} 
A vallás annyiban különleges átmeneti tér, hogy amíg egy színházi előadás két órára és a színpadra és a nézőtérre vonatkozik, addig a vallás „színpada” az egész univerzum, tere pedig a világ teremtése előttől az örökkévalóságig terjed. Eliade felhívja a figyelmet arra, hogy a vallásos ember számára ez a „vallásos térélmény” nem csupán egy a lehetséges fantázia világok közül, hanem: „A vallásos ember kívánsága, hogy szentségben éljen, azt jelenti, hogy az objektív valóságban kíván élni, nem akar a szubjektív élmények végtelen viszonylagosságának foglya maradni: egy valóságos és hatni képes - nem pedig illuzórikus - világban kíván állni. [...] a vallásos ember számára minden világ: szent világ." ${ }^{10}$ Tehát a vallásos ember számára a vallás tere a valóság tere.

A vallás úgy hoz létre egy új realitást, hogy közben nem szakad el a profán valóságtól, viszont az élet töredezettsége ellenére sem ragad bele a látható világ reménytelenségébe: „Isten mindenütt jelenvalósága győzi le a szorongást, hogy az embernek nincs tere önmaga számára. Bátorságot ad ahhoz, hogy elfogadjuk a térbeli létezés bizonytalanságait és szorongásait. Isten mindenütt jelenvalóságának bizonyosságában otthon vagyunk, és nem vagyunk otthon, begyökerezettek vagyunk, és gyökértelenek, van állandó helyünk, és zarándokok vagyunk, van helyünk, és nincs helyünk, ismerősek vagyunk egy hely számára, és egyetlen hely sem ismer minket."

A vallás köztes tere nemcsak új perspektívákat ad az életünk szemlélésére, hanem formálja is az életünket. Ahogy Grözinger írja: „Az egyház sajátossága s egyben feladata is, hogy az Istennel való kapcsolat többletét ne hagyja egy absztrakt életidegen posztulátummá válni, hanem egy konkrét történetbe integrálja, (...) az emberek Istennel kapcsolatos átéléseinek történetébe." ${ }^{12}$

Az élménygyüjtés és tapasztalat megosztásának ebben a közösségi terében interaktív résztvevőként hat a hívő ember a vallásos térre, és saját értelmezésében az is visszahat rá. Vallásos ember megélésében tehát nem konstruálja, hanem rátalál az igazság szent valóságára, vagy az Igazság találja meg őt. Olyan vallásos térbe lép be, amely a kézzelfogható valóssággal párhuzamosan és az egyénen kívül is létezik.

\footnotetext{
${ }^{10}$ Eliade: 21.

${ }^{11}$ Tillich: 226.

${ }^{12}$ Grözinger: 47 .
} 


\section{A MÍTOSZ ÉS RÍTUS}

A köztes tér történeti dimenzióját a mítosz vagy meta-narratíva foglalja keretbe, a rítusok pedig ennek kiábrázolásában kapnak szerepet. Ahogy Kluckhohn fogalmaz: „amíg a mítosz egy szó-szimbólumokból álló rendszer, addig a rítus egy tárgyi és cselekvési szimbólumokból felépülő rendszer."13

A vallások köztes terének története van, és ebbe a meta-narratívába léphetünk be egyéni és közösségi szinten egyaránt. „Kollektív identitáson, vagyis Mi-azonosságon azt a képet értjük, amelyet egy csoport önmagáról fest, $s$ amellyel a tagok azonosulnak. A kollektív identitás azonosulás kérdése a résztvevő egyének részéről: »önmagában nem létezik«, hanem mindig csak annyiban, amennyiben egyesek hitet tesznek mellette. Ereje attól függ, mennyire él elevenen a csoporttagok tudatában, mennyire képes motiválni a gondolkodásukat és a cselekvésüket." ${ }^{14} \mathrm{~Eb}$ ből a szempontból vallásosnak lenni annyi, mint felvenni egy szempontrendszert, s mintegy benne állni olyan történetfolyamban, amely a születés előttől az idők végéig fut, és rendet teremt a makrokozmoszban, illetve bekapcsolódási lehetöséget ad az egyén számára, hogy az egyéni mikrokozmoszában is rendet tegyen. A vallásos ember a köztes térbe bekapcsolódással olyan meta-történet részese lehet, amely segít értelmezni az életet, nevet ad személyes vágyaknak, szókincset ad érzéseknek: „Minden csoport, amely maradandónak vagy fontosnak tételezi fel önmagát, kifejleszt megosztott történeteket, amelyek nem csupán a csoport identitását határozzák meg, hanem olyan eszközöket is felkínálnak, amelyeknek irányító szerepe révén a csoport tagjai maguk is felfedezik személyes életük jelentését."15

Az örökölt, átvett olvasási mód ugyanis rendszerezi élményeinket, hogy választ ad az élet alapvető és végső kérdéseire, mint például: „Mi a végső realitás? Milyen a körülöttem lévő világ? Mi az ember? Mi történik a halál után? Mi a tudás végső forrása? Honnan tudom, hogy mi a jó és a rossz? Mi a célja az emberi történelemnek?" ${ }^{16}$ Az így értelmezett valóságban, a saját életvilágunkban a hit a tapasztalás alapjává lesz. A vallás tehát az egyéni életet transzcendentálja azáltal, hogy a végső felől értelmezi és egy értelmezési közösségbe integrálja. A vallási meta-elbeszélés tehát egy folyamatosan változó, perspektívái tekintetében mégis állandó rendszer; tradíció, amely egyrészt szabályrendszert nyújt például a keresztyén közösségek életére nézve, másrészt az egyes ember életét is az üdvtörténetbe integrálja.

A köztes térnek azonban nemcsak idői/idő feletti, hanem térbeli dimenziója is van a hívő ember számára. Szimbólumok és jelek utalnak a köztes valóságának

\footnotetext{
${ }^{13}$ Kluckhohn: 58 .

${ }^{14}$ Assmann: 131.

${ }^{15}$ Pataki: 298.

${ }^{16}$ Sire: 20.
} 
jelenlétére. Templomok, útszéli keresztek, zászlók, szobrok, szent iratok, gyertyák, ruhák, harangok, csengettyűk, de akár a természet is és még sorolhatnánk mennyi minden a köztes térbe hívó jelként van jelen életünkben. Ha engedünk hívásuknak, akkor kapnak szerepet a szent cselekvéssorozatok, rítusok életünkben.

\section{SZOKÁSHUROK A RÍTUS MEGÉLÉSÉBEN}

A keresztyénség is számos belépési küszöböt, rítust kínál a ma embere számára is, hogy ebbe az átmeneti térbe beléphessen. Az életünk nagy váltásaiban egyszeri rítusok lehetnek segítségünkre (például elengedés, befogadás, megtérés, keresztelés, konfirmáció, esküvő, temetés). E mellett vannak olyan megismételt rítusaink, mint a vasárnapi istentisztelet, az ünnepek, de vannak a hétköznapi rítusaink, amelyek egy része közösségi, más része pedig egyéni (szokások).

A rítusok olyan egyéni és közösségi szokások, amelyeken keresztül be tudunk lépni a vallás átmeneti terébe. ${ }^{17} \mathrm{~A}$ rítus átélésének egy fontos eleme a küszöb élmény, amikor a szent térbe lépő hátrahagy valamit, hogy egy másik térbe léphessen. ${ }^{18}$ Még akkor is, hogyha fizikailag nem hagyja el a teret, de számára egy átlényegült párhuzamos játéktérben találja magát. Az ilyen átlépési küszöbök lehetnek időhöz és/vagy térhez kötöttek. Az időhöz kötöttség például az, amikor valaki reggelenként egy megszokott időben imádkozik, vagy vasárnap templomba jár. Térhez kötött például egy útszéli kereszt, amely az ott elhaladót emlékezteti arra, hogy keresztet vessen, vagy imádkozzon. Van olyan átlépési küszöb, amelyet a közösség hagyományoz ránk, van olyan, amit a családi szokások (pl. asztali áldás), és van, ami egyénileg kialakított vallásos szokás (pl. a lakás küszöbén átlépve imádkozás az aznapi találkozásokért, mosogatás közben imádság az asztaltársaságban részt vevőkért, stb.)

A rítusok mint vallásos szokások maguk is bírnak a profán szokások forgatókönyvének elemeivel, rájuk is érvényes a szokáshurok jelensége. ${ }^{19}$ Ennek az első része a jel: egy olyan térben vagy időben megjelenő momentum, amely beindítja a szokás hatásmechanizmusát ${ }^{20}$ (pl. a déli harangszó vagy imazsámoly).

A vallásos szokással bíró ember számára a jel adja meg a kezdő lökést, amely beindít egy rutinszerű cselekvést, és ezt követi a szokáshurok második eleme: a ru-

${ }^{17}$ A rítusok az emberi életben mindig is az átmenetek segítői voltak, a kilépés, az átlépés kiábrázolásai. Máté-Tóth: 142.

${ }^{18}$ A hátra hagyás nem mindig fizikai jellegü, lehet akár a „világ zajának” háthagyása és fókuszált figyelem a Szentre irányítása is (pl. ima, meditáció).

${ }^{19}$ Spilka: 365 .

${ }^{20}$ Duhigg: 19 . 
tin. ${ }^{21}$ Egy bizonyos jel egy olyan határmechanizmust indít el, amely végigfut tudatosan vagy akár kevésbé tudatosan a vallásos szokást gyakorló emberben, például: ha meglát egy keresztet, és automatikusan keresztet vet / meglát egy imazsámolyt és megjelenik benne a hiány, vagy annak a vágya, hogy jó lenne imádkozni / megjelenik a napi igeszakasz a telefonján, és automatikusan végigolvassa.

Hogyha a rutin rendben végigfut, menetrendszerüen jelenik meg a szokáshurok harmadik eleme, amit jutalomnak nevezünk. A megjelent igény kielégül, valamilyen jó érzés keríti hatalmába azt, aki a vallásos rítus lépéseit követve megoldja az előtte lévő feladatot, átlép a küszöbön, eljut a profán világból a szent térbe. A szokásmechanizmuson végigmenni olyan, mint egy elöre elkészített rejtvényt megfejteni. Mások vagy saját magam által előre kitalált játékszabály mentén végigjárva jutok el egyik térből a másikba. Persze előfordulhat az életben, hogy úgy találkozom a szenttel, hogy azt nem vártam, vagy nem készültem rá, de az esetek többségében a készület, a ráhangoltság és a szükséges lépések megtétele segíthet abban, hogy a szenttel való találkozás a mindennapok részévé válhasson. Az, hogy milyen szokásrendszereink alakulnak ki és erősödnek meg, függ a személyiségünktől, a megtett életutunktól, a környezetünk hatásaitól és a hitünk alakulásától egyaránt. Más és más lehet a motiváció és a jutalom a különböző életkorszakainkban és hitfejlődési szinteken. ${ }^{22}$

\section{A RÍTUS MINT SÜRÍTÉS}

„A rítusok magukba foglalják a szokások, belső képek, szimbólumok, mozgások és érzések szintézisét" ${ }^{23}$ - írja David Solomon szerzőtársaival arról, hogy a rítusok mi mindent sürítenek magukba. Ez úgy mehet végbe, hogy a rítusokban a „belső beszéd" szabályai érvényesek.

Lev Vigotszkij ír arról, hogy a gondolkodás és a beszédhasználat összefügg egymással. A kisgyermek életében a nyelvhasználat, a hangos beszéd és a gondolkodás együtt fejlődik, viszont a nyelvhasználat idővel kettéválik: a szociális beszédre és az úgynevezett belső beszédre: „A gyerek a hangos beszéd segítségével elérte már a tárgyi világ absztrahálásának bizonyos, elég magas fokát. Most új feladat vár rá: el kell vonatkoztatnia magának a beszédnek az érzéki oldalától, át kell térnie az elvont beszédre, amely nem a szavakat, hanem a szavak jelképeit használja." ${ }^{24} \mathrm{~A}$ bel-

\footnotetext{
${ }^{21}$ „A rítusok rutinná vált cselekvések, melyeket rendszeresen ismétlünk.” Paloutzian: 269.

${ }^{22}$ Minden ember számára van egy általa belátható világ, s ebben a „játéktérben” a Végsőről alkotott képünk fejlődésen megy át, s fejlődési szakaszonként más és más sémarendszer szerint töltjük meg. Vö. Streib: 37 .

${ }^{23}$ Solomon, et al.: 1 .

${ }^{24}$ Vigotszkij: 261-262.
} 
ső beszéd szabályai mások, mint a hangos beszédé, ugyanis itt nem kell mindent „kimondanunk”, hogy megértsük. Gondolataink nyelve ugyanis jelentéstartalmakat, szimbólumokat, metaforákat, érzéseket, impressziókat is tartalmaz, amik a hétköznapi nyelvben leírhatatlanok.

A rítust is érthetjük, hogy közben nem minden írható le belöle a racionalitás eszközeivel. A vallás köztes terében is benne lehetünk úgy, hogy intuitív átélésünk nem foglalható emberi szavakba. Színek, illatok, hangulati belső képek lehetnek jelen az egyéni álélésben valóságosan anélkül, hogy a belső eseménysor külső kommunikációja megtörténne. Külső szemlélőként következtethetünk a nonverbális jelekből, hogy a másik emberben valami zajlik a vallásos átélés során, de még a szóbeli megosztás vagy eljátszás (pl. bibliodráma) esetén is az átélés jelentős része belső titok marad, vagy egyszerüen nem leírható a szociális beszéd eszközrendszerével. Az alábbi ábra azt szemlélteti, hogy az átmeneti térbe milyen kapun keresztül léphetünk be, és ezekhez többnyire rítusok is párosulnak.

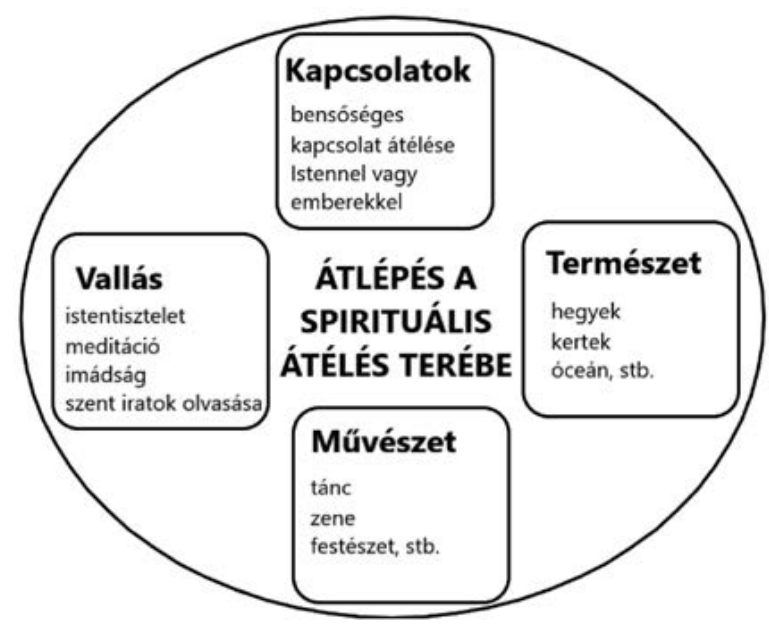

1. ábra ${ }^{25}$

A rítus elindító jele lehet a transzcendenssel való kapcsolat intermediális terébe való belépéshez a vallás egyéni és közösségi gyakorlatai, megjelenhet ez emberi kapcsolatok számos formájában, de a természet és a művészet is ajtót nyithat a végtelenre. 
A kérdés, hogy ami sok-sok nemzedéken keresztül adott volt a rítusok terén, vajon átadódott, átadódik-e a következő generáció számára? Vajon lesz-e látása az újabb nemzedékeknek, hogy kódolják azokat a jeleket, amelyek a vallás köztes terébe adhatnak belépési lehetőséget?

\section{BEFEJEZÉS}

Az emberiség történetének folyamán számos belépési pontot dolgozott ki és adott mintát saját belépési szokásaink kialakítására. Ezeket a jeleket azonban nem mindenki tekinti hívó jelnek, de aki belép rajta, annak egy új világ tárul fel. Ezt a jelenséget és lehetőséget irodalmi köntösben ábrázolta C. S. Lewis Az oroszlán, a boszorkány és a különös ruhásszekrény címü művében. Az átmeneti térbe belépés témájának illusztrálásaként hadd álljon itt az alábbi idézet ebből a műből:

Végül bekukucskáltak egy üres szobába, aminek egyik sarkában régi, kopott ruhászszekrényt pillantottak meg. Egyik ajtaja üvegezett volt. - Semmi izgalmas! - sóhajtott fel Peter, avval kitrappolt a szobából. A többiek követték, kivéve Lucyt, ő hátramaradt, bár tudta, hogy fölösleges a szekrényajtóval bajlódnia, úgyis zárva lesz. Legnagyobb meglepetésére, már az első próbálkozásra könnyedén kinyílt... Kapta magát és hirtelen belépett a szekrénybe, arcát a kabátok közé fúrta... Tovább lépett, és újabb sor kabátot talált... Két vagy három lépést haladhatott így elöre. Még mindig nem tapintotta a hátlapot. Lucy: - Nahát! Ez egy nagyon különös szekrény! - gondolta, ahogy egyre beljebb és beljebb haladt. A kabátokat egyre-másra tologatta félre maga előtt. Nemsokára úgy hallotta, mintha valami csikorogna a talpa alatt. - Csak nem ennyi molyirtó golyócskán taposok! - tűnődött. Lehajolt, hogy kitapogassa. De ahelyett, hogy a szekrény kemény fáját érezte volna, az ujjai valami puha, de hideg dolgot érintettek. - Nagyon különös - ámuldozott egyre jobban, és megint tett néhány lépést elöre. A következő pillanatban érezte, hogy az arcát súrolja valami. De ez a valami nem a kabátok puha, lágy anyaga volt, hanem valami kemény, szürős dolog. - Mintha száraz faágak lennének! - próbált valami magyarázatot találni. Hirtelen világosság támadt a feje fölött. Tudta, hogy a szekrénynek közvetlenül a háta mögött kell lennie, de ahogy hátrapillantott, valahogy távolabbnak tünt. Valami puha és hideg hullott a fejére. Pillanatokkal később már világosan láthatta, hogy havas erdő közepén áll, éjszaka, miközben hópelyhek szállingóznak mindenfelé a levegőben. ${ }^{26}$

\footnotetext{
${ }^{26}$ Lewis: 5-6.
} 


\section{IRODALOM}

Assmann, Jan: A kulturális emlékezet - Írás, emlékezés és politikai identitás a korai magaskultúrákban, Budapest, Atlantisz, 1999.

DuHigG, Charles: A szokás hatalma - Miért tesszük azt, amit teszünk, és hogyan változtassunk rajta? Solymár, Casparus Kiadó, 2015.

Eliade, Mircea: A szent és a profán, Budapest, Helikon, 2014.

Gerkin, Charles V.: The Living Human Dokument - Re-Visioning Pastoral Counseling in a Hermeneutical Mode, Nashville, Abingdon Press, 1984.

GrözINGER, Albrecht: Die Kirche - ist sie noch zu retten? - Anstiftungen für das Christentum in postmoderner Gesellschaft, Gütersloh, Chr. Kaiser/Gütersloher Verlagshau, 1998.

KLucкhoнn, Clyde: „Myths and Rituals - A General Theory”, Harvard Theological Review 35. 1942, $42-79$.

KodÁcsY-Simon Eszter - SzabónÉ LÁszLó Lilla: „Kisgyermek a családban - A család és a koragyermekkor valláslélektani megközelítése", in Siba Balázs - Szabóné LÁszló Lilla - PÁNGYÁNSzKY Ágnes (szerk.): Együtt a hit útján - Gyülekezetpedagógiai kézikönyv, Budapest, Kálvin Kiadó, 2019, 87-113.

LEwis, C. S.: Az oroszlán, a boszorkány és a különös ruhásszekrény, Budapest, Szent István Társulat, 1988.

MacKInlay, Elsabeth: Spiritual Growth and Care in the Fourth Age of Life, London-Philadelphia, Jessica Kingsley Publishers, 2006.

MáтÉ-Tóтн András: Vallásnézet - A kelet-közép-európai átmenet vallástudományi értelmezése, Kolozsvár, Korunk-Komp-Press, 2014.

NÉмeTh Dávid: Hit és nevelés - Valláslélektani szemléletmód a mai valláspedagógiában, Budapest, Károli Gáspár Református Egyetem Hittudományi Kara, 2002.

Paloutzian, Raymond F.: Invitation to the psychology of religion. Third Edition, New York, London, The Guilford Press, 2017.

PATAKI Ferenc: Élettörténet és identitás, Budapest, Osiris, 2001.

SIRE, James W.: Naming the Elephant - Woldview as a Concept, Downers Grove, InterVarsity Press, 2004.

Solomon, David - Lo, Ping-Cheung - Fan, Ruiping - EngelHardt, H. Tristram: „Ritual as a Cardinal Category of Moral Reality: An Introduction", in uök (ed.): Ritual and the Moral Life Reclaiming the Tradition, Dordrecht, Springer, 2012, 1-16.

SPIlKa, Bernard: „Religious Practice, Ritual, and Prayer”, in Paloutzian, Raymond E. - Park, Crystal L. (ed.): Handbook of Religion and Spirituality, New York, The Guilford Press, 2005, 365-377.

Streib, Heinz: Hermeneutics of Metaphor - Symbol and Narrativ in Faith Development Theory, Frankfurt am Main, Peter Lang, 1991.

Tillich, Paul: Rendszeres teológia, Budapest, Osiris Kiadó, 2002.

Vigotszkij, Lev Szemjonovics: Gondolkodás és beszéd, Budapest, TREZOR, 2000.

Weinschenk, Susan: 100 Things Every Presenter Needs to Know About People, Berkeley, New Riders, 2011.

Winnicott, Donald W.: Játszás és valóság, Budapest, Animula, 1999.

ZAKARI, Dotchamou: 251 best quotes of one the greatest motivators: John C. Maxwell, Kindle Edition, 2017. 